\section{Thoughts for the New Year}

Almost 400 years ago, probably in 1728, Johann Sebastian Bach composed one of his cantatas for New Year's day, BWV 171, which was doubtless performed in one of the city of Leipzig's churches. The bass recitative intones a prayer to God for protection from fire, disease and war ("Behüt uns dieses Jahr/Für Feuer, Pest und Kriegsgefahr!”). ${ }^{1}$ In our own time we seem to have advanced very little since then (or, we have advanced and subsequently decayed), for these selfsame preoccupations are again uppermost in our minds as we launch into 2016.

In Bach's day, "Fire" may have simply been the danger of urban conflagration (cf. the Great Fire of London in 1666), albeit that a more cataclysmic significance has biblical authority. ${ }^{2}$ With modern medical practice in its (pre)infancy (especially considering a certain regression following the pioneering work of von Hohenheim [1] 200 years earlier), infectious disease in particular was a real danger (cf. the Great Plague of London in 1665). As for war, the preceding decade had experienced a number of hostilities against the Ottomans (by Austria and Venice), and belligerent aggression (by Spain).

Moving forward to our own time, although cataclysmic destruction by fire (by triggering the explosion of a significant proportion of the stockpiled nuclear warheads) was a real possibility during the Cold War, the best contemporary interpretation is that it refers to the threat of global warming. Its destructive action will be slow and insidious (unless some unsuspected nonlinearities in the world Gestalt suddenly emerge). Gradual global warming is already an undisputed reality (even if the cause remains controversial), ${ }^{3}$ and if unchecked could well lead to the extinction of $H$. sapiens.

"Disease" very aptly refers to the growing antimicrobial resistance of bacteria and other microbes, which has greatly attenuated the ability of modern medical practice to tackle many infectious diseases. If present trends continue, pharmacotherapy will soon become almost completely impotent against microbial pathogens $[2,3]$. This issue is now being discussed at the highest levels. For example, the UK Prime Minister announced a review on antimicrobial resistance last year [4].

As for war, the general public could be forgiven if they had lost count of the number of military conflicts presently going on around the world. Many of them are too remote and minor in extent to merit the attention of journalists, but some of them are flanked by prominent terrorist actions such as the explosions and shooting on 13 November in Paris, the effects of which were and are being felt far beyond that city.

The cantata continues, "Gib unsrer Obrigkeit/und dem gesamten Lande/Dein Heil des Segens zu erkennen.” In Bach's day the meaning of "Dein Heil des Segens" would have been understood clearly enough and especially appropriately mentioned around Christmas. In our own time much uncertainty prevails. Prince Charles of the United Kingdom, in line to inherit the title "Fidei defensor", has suggested he would prefer to be known as defender of the faiths, in plural. Perhaps the best we can do in our time is to ask those in authority to abide by the seven "Nolan principles" formulated by the Committee on Standards in Public Life. ${ }^{4}$ One would thought that this does not present an insuperable challenge, but the general public has probably also lost count of the number of public scandals, including fraudulent claims for expenses by UK Members of Parliament (2009), phone hacking by journalists at the News of the World (2011), and the fraudulent manipulation of the London Interbank Offered Rate (LIBOR) by colluding traders (2012). When it comes to the European Union, the opportunities for fraud are enormously multiplied due to the size and complexity of the organization. The report Financial Control and Fraud in the Community [5] quotes the Court of Auditors report asserting that "there has been 'little or no improvement' in the Community's financial management, despite repeated criticisms made in previous reports ... the Commission and Member States 'have generally not succeeded in establishing clear, coherent and effective administrative control systems"'. That was for 1992. Moving on to 2013, the European Court of Auditors (ECA) noted that "Payments for 2013 are materially affected by error. The ECA therefore gives an adverse opinion on their legality and regularity" [6]. It is sometimes argued that the estimated error rate (close to 5\%) is nevertheless a small percentage; it could equally cogently be argued that breaches of the spirit of probity are much worse than these documented breaches of the letter of the law. The expenses claimed by members of the European parliament are an egregious example of the former.

Hermann Keyserling quotes a Dresden bookseller: "Before, when we still had a King, I could close up my shop and go home and look up to the lights in the castle

\footnotetext{
The text was written by Christian Friedrich Henrici-Picander in 1728.

Peter 3,7.

3 A gigantic (around 50,000 participants) international Climate Change Conference was organized under the auspices of the United Nations from 30 November until 12 December in Paris, with the goal of attempting to limit the warming to $+2 \mathrm{~K}$.

4 Set up by the UK Government in 1994.
} 
with a feeling of security; on holiday evenings he was still at work, on things beyond my understanding. Today I feel insecure. I need a close-fitting coat to feel safe in my skin" [7]. It seems that since then that has become a permanent characteristic of our affairs. Man was created in God's image, but with all the technology at his disposal he is unable to order his affairs in a laudable fashion.

Or does the problem lie in "unsrer Obrigkeit"? What, people are now asking, added value does it bring? Ever more strident exhortations from above to reduce carbon emissions, alcohol consumption, water usage etc. etc. increasingly fall on deaf ears. Disenchantment with "unsrer Obrigkeit" goes far beyond more or less petty scandals and fraud; it now appears that numerous highlevel regulatory agencies (the European Food Safety Authority is a notorious example) are riddled with corruption driven by venality. Nevertheless, given our complex urban society and industrial infrastructure, ${ }^{5}$ some organization is very necessary. This limits what might be achievable by "intelligent anarchy". The production of books and the construction and programming of Internet servers, very necessary for the dissemination of information, the operation of railways and airlines for bringing us to meetings, and the maintenance of supply chains for food and other basic necessities all rely on an intricate web of human relationships.

Perhaps the greatest danger comes from growing resentment, by a growing proportion of the general population, of the abuses that people can get away with. ${ }^{6}$ Such resentment could gradually percolate throughout society, paralysing its functioning as we know it. Sustaining our intricate society requires adherence to, nay, the upholding of, an almost ineffable way of doing things, perhaps epitomized by Figure 1. That scene, swept away forever by a mixture of ill-conceived futurism and corruption, captures the unassuming devotion to duty (as well as countless other ramifications) that is so necessary for the harmonious living together and well-being of a nation. Ominously, the "genuine progress indicator" (GPI) seems to have reached a plateau around 1978 [8]. One of the corollaries of that observation is that the world economy may never now recover from the latest series of recessions, unless there is some truly radical change of policy.

Be that as it may, some sort of progress might be possible via a way intermediate between centralized

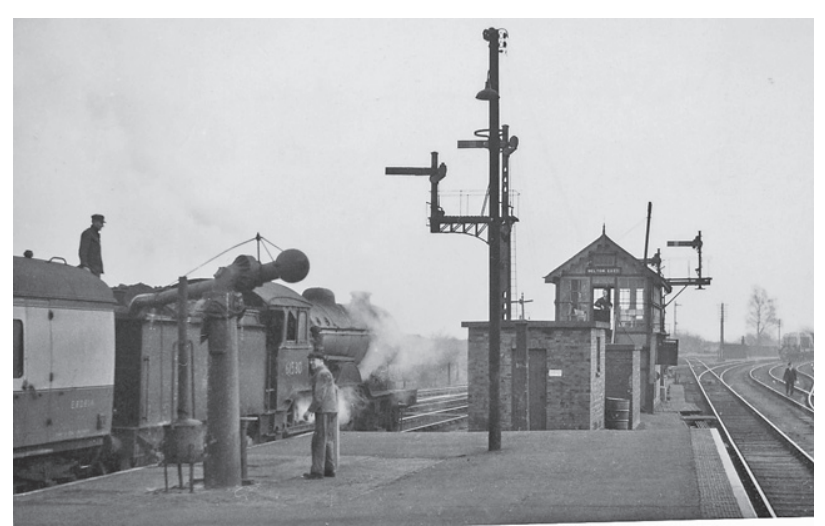

Figure 1. Melton Constable (Norfolk, England) railway station in 1958 (photographer unknown).

control within ever-larger units (such as the European Union) and the uncoördinated actions of individuals: regarding healthcare, for example, individual hospitals could decide on their own policies for tackling antimicrobial resistance, and individuals decide on their own personal lifestyles to maintain good health. Such a working out of subsidiarity would represent a highly effective exploitation of today's almost universal dissemination of information on almost every conceivable topic.

J.J. RAMSDEN

\section{References}

1. J.J. Ramsden, Paracelsus: the measurable and the unmeasurable. Psyche: Problems, Perspectives 4 (2004) $52-88$.

2. Antimicrobial Resistance: Global Report on Surveillance. Geneva: World Health Organization (WHO) (2014).

3. Worldwide Country Situation Analysis: Response to Antimicrobial Resistance. Geneva: World Health Organization (WHO) (2015).

4. J. O'Neill, Antimicrobial Resistance: Tackling a Crisis for the Health and Wealth of Nations. London: HM Government \& Wellcome Trust (2014).

5. Financial Control and Fraud in the Community (12th Report of the Select Committee on the European Communities) (HL Paper 75). London: HMSO (1994).

6. ECA Annual Report (2013).

7. H. Keyserling, Europe (Das Spectrum Europas), p. 115. London: Jonathan Cape (1928).

8. I. Kubiszewski et al., Beyond GDP: Measuring and achieving global genuine progress. Ecological Economics 93 (2013) 57-68.

5 In the UK, the first country to industrialize, by around 1900 only $11 \%$ of the workforce was still employed in agriculture (less than $1 \%$ today). The corresponding figure for Germany was around 30\%, and even more for France (around 3\% today).

6 To give a specific example, Basil Fozard, medical director of the Royal Bournemouth and Christchurch Hospitals NHS Foundation Trust "retired from his $£ 135,000$ rôle for a month in order to start drawing on his $£ 1.9$ million NHS pension pot, before returning to work on an increased salary of $£ 152,000 "$ - apparently a legal procedure, although surely contrary to the spirit of the Nolan Principles (reported by the Tax Payers' Alliance (TPA) on 13 November 2015; the events happened in the summer of 2015). 